\title{
EFFECTS OF VARIOUS NITRIC OXIDE SYNTHASE INHIBITORS ON QUINOLINIC ACID-INDUICD NEURONAL INJURY IN RATS
}

\author{
Ivana D. Vasiljević1, Marina D. Jovanović1, Miodrag Čolić1, Rosa Mihajlović2, \\ Mirjana Đukić ${ }^{3}$, Milica Ninković ${ }^{1}$, Živorad Maličević ${ }^{1}$ \\ ${ }_{1}^{1}$ Institute for Medical Research, Military Medical Academy \\ Institute of rehabilitation \\ 3 University School of Pharmacy, Belgrade
}

\begin{abstract}
Summary: The aetiology of neuronal death in neurodegenerative diseases, including Huntington's disease, is still unknown. There could be a complex interplay among altered energy metabolism, excitotoxicity and oxidative stress. Our aim was to examine the effects of intrastriatal injection of a selective inhibitor of neuronal nitric oxide synthase, 7-nitroindazole, and a non-specific potent nitric oxide synthase inhibitor, N $\omega$-nitro-L-arginine methyl ester, in order to study the possible involvement of glutathione, an important antioxidant, in quinolinic acid-induced striatal toxicity in the rat. Unilateral administration of quinolinic acid to rat striatum in a single dose of $150 \mathrm{nmol} / \mathrm{L}$ was used as a model of Huntington's disease. The other group of animals were pretreated with 7nitroindazole and $\mathrm{N} \omega$-nitro-L-arginine methyl ester, respectively. Control groups were treated with saline solution and olive oil, respectively. Content of total glutathione, was increased in the ipsi- and contralateral striatum, forebrain cortex, basal forebrain and hippocampus in the groups treated with nitric oxid synthase inhibitors and quinolinic acid compared to the quinolinic acid-treated animals. These results support the hypothesis that oxygen free radicals contribute to excitotoxic neuronal injury, and also that nitric oxide synthase inhibitors could be potential neuroprotective agents in Huntington's disease.
\end{abstract} tathione

Key words: Huntington's disease; quinolinic acid; N $\omega$-nitro-L-arginine methyl ester; 7-nitroindazole; glu-

\section{Introduction}

The aetiology of neuronal death in neurodegenerative diseases is still a mystery; however, evidence of defects in energy metabolism, excitotoxicity and oxidative damage is increasingly convincing. It is likely that there is a complex interplay among these mechanisms. A defect in energy metabolism may lead to neuronal depolarization, activation of $\mathrm{N}$-methyl-D-aspartate (NMDA) excitatory amino-acid receptors, and increases in intracellular calcium, which are buffered by mitochondria $(1,2)$.

\footnotetext{
Address for correspodence

Ivana Vasiljević

Institute for Medical Research

Military Medical Academy

Crnotravska 17

11000 Belgrade

E-mail: ivanav13@yahoo.ca
}

Neurotoxicity of excitatory amino-acids contributes to the pathogenesis of many forms of acute and chronic neuronal injuries including Huntington's disease (HD). The NMDA class of glutamate receptors is believed to play a prominent role in the pathogenesis of CNS excitotoxicity (3). Quinolinic acid (QA), a 2,3-pyridine dicarboxilic acid, has drown considerable attention as an endogenous excitotoxic metabolite of L-tryptophan that mediates neuronal injury through NMDA receptor activation and subsequent elevations of intracellular calcium, oxidative stress and lipid peroxidation $(4,5)$. Excitotoxic striatal lesions induced by $\mathrm{QA}$, a model of $\mathrm{HD}$, were used to test neuroprotective actions of nitric oxide synthase (NOS) inhibitors 7nitroindazole (7-NI), and $\mathrm{N} \omega$-nitro-L-arginine methyl ester (L-NAME). 7-NI is known to be relatively specific for neuronal NOS (nNOS), whereas L-NAME affects both nNOS and endotelial NOS (eNOS) $(6,7)$. 
There are several reports showing that overactivation of NMDA receptors mediates cell death and neurotoxicity. NMDA receptor activation increases $\mathrm{NO}$ syntesis probably by increasing intracellular calcium which binds to calmodulin, allowing it to activate NOS. Striatal microinjection of QA is associated with neuronal damage through NMDA receptor activation and increased NOS activity (8).

If NMDA excitotoxic process does play a role in neuronal degeneration in $\mathrm{HD}$, it is expected that the neurons containing high densities of these receptors are preferentially vulnerable resulting in a depletion of NMDA receptors. The vulnerability of signaling systems to oxidative stress is influenced by intracellular glutathione levels (GSH), indicating that cell-selective susceptibility to inhibition of signal transduction systems by oxidative stress can arise from cellular variations in antioxidant capacity $(9,10)$.

Glutathione ( $\gamma$-glutamylcysteinylglycine) is a naturally occurring tripeptide which, because of its nucleophilic and reducing properties, plays a central role in many metabolic pathways as well as in the antioxidant defense system of most aerobic cells (11).

In view of the above, the present study was undertaken to examine whether the content of total glutathione receiving intracerebral injections of $\mathrm{QA}$ can be modulated with pretreatment with 7-NI and LNAME, respectively.

\section{Material and Methods}

\section{Animals}

The study was carried out on adult Wistar rats of both sexes, with body weight about $250 \mathrm{~g}$. Animals were divided into four groups and were put in macrolen cages (Erath, FRG). Animals had free access to food and water. Average microclimate conditions were as follows: room temperature $23 \pm 2{ }^{\circ} \mathrm{C}$, air humidity $55 \pm 10 \%$, air was conditioned by 10 to 50 exchanges per hour, and light regimen was in a cycle of 12 hours from 7 to 19 hours. These animals were anesthetized by pentobarbital sodium i.p. in a dose of $0.0405 \mathrm{~g} / \mathrm{kg}$ b.w., and were placed in a stereotaxic frame.

\section{Experimental procedure}

The rats were divided into seven groups (according to drug treatment) and each group was composed of 8 animals. The first group received an unilateral injection of QA (Aldrich Chemical Company, Inc.) in a single dose of $250.7 \mathrm{mg}$ (dissolved in $\mathrm{H}_{2} \mathrm{O}$ ) using stereotaxic instrument for small animals as coordinate for striatum $(8.4 ; 2.4 ; 5.0 \mathrm{~mm})$. The second and third groups were treated with 7-NI (Sigma Chemical Co. U.S.A.; $1 \times 10^{-4} \mathrm{~g}$ dissolved in olive oil)+QA and 7-
NI+saline solution (ss). The fourth and fifth groups were treated with L-NAME (Sigma Chemical Co. U.S.A.; $1 \times 100{ }^{4} \mathrm{~g}$ dissolved in saline solution)+QA and L-NAME+saline solution (ss). 7-NI was immediately used before neurotoxin in contrast to L-NAME that was used thirty minutes before QA. The sixth group received the same volume but only 0.154 $\mathrm{mmol} / \mathrm{L}$ of saline solution and served as a controlsham-operated (Kss). Finally, the seventh group received the same volume of olive oil and also served as a control (Koo). In all treated animals the injected intracerebral volume was $10 \times 106 \mathrm{~mL}$.

All animals were killed by decapitation 7 days after the treatment and the brains immediately removed. Ipsi- and contralateral striatum, forebrain cortex, basal forebrain as well as hippocampus from individual animals were quickly isolated and homogenized in ice-cold buffer containing $0.25 \mathrm{~mol}$ of sucrose, $0.1 \mathrm{mmol}$ of EDTA, $50 \mathrm{mmol}$ of K-Na phosphate buffer, $\mathrm{pH}=7.2$. Homogenates were centrifuged twice at $1580 \mathrm{~g}$ for $15 \mathrm{~min}$ at $4{ }^{\circ} \mathrm{C}$. The supernatant obtained by this procedure was then frozen and stored at $70{ }^{\circ} \mathrm{C}(12)$.

\section{Content of total glutathione measurement}

A prepared crude mitochondrial fraction of striatum, forebrain cortex, basal forebrain and hippocampus was used for the appropriate biochemical analysis. Content of total glutathione (GSH+1/2 GSSG, in GSH equivalents) was determined with DTNB-GSSG reductase recycling assay. The rate of formation of 5-thio-2nitrobenzoic acid (TNB), which is proportional to the total GSH concentration, was followed spectrophotometrically at $412 \mathrm{~nm}$ (13).

\section{Protein measurement}

The content of protein in the rat brain homogenates (ipsi- and contralateral striatum, forebrain cortex, basal forebrain and hippocampus) was measured by the method of Lowry et al. using bovine serum albumin (Sigma) as standard (14).

\section{Data presentation and analysis}

All experiments were done in $n=8$. Data are expressed as means \pm SD. Differences among groups were examined using Student's independent t-test. Statistical significance was accepted at $\mathrm{p}<0.05$.

\section{Results}

Content of total glutathione in the rat striatum

Results presented in Figure 1 show the content of total glutathione (nmol GSH/mg prot.) in ipsi- and contralateral striatum homogenates. QA injection re- 


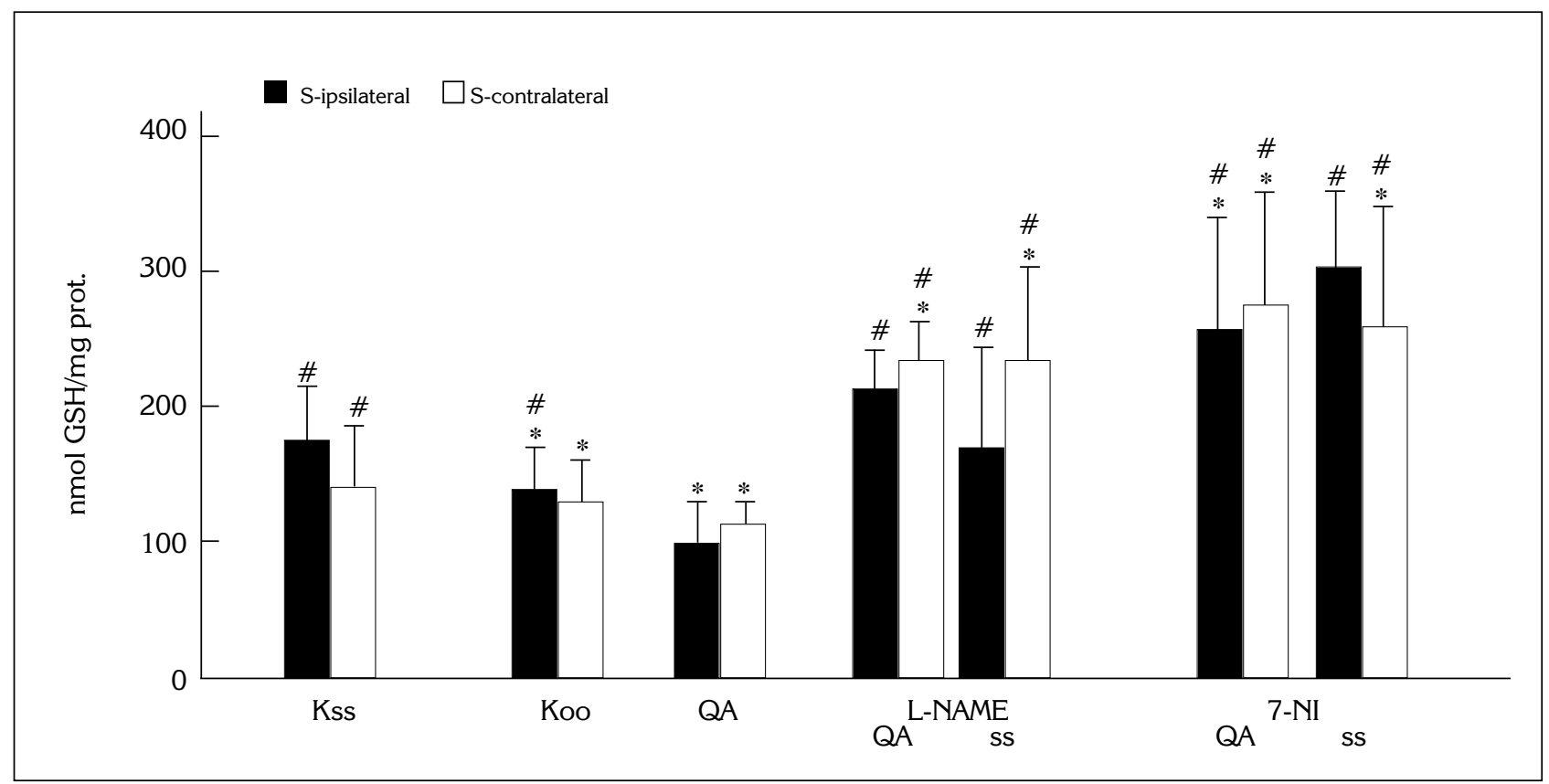

Figure 1. Content of total glutathione in the ipsi- and contralateral striatum of QA- and NOS inhibitors-treated Wistar rats. ( $\mathrm{Si}, \mathrm{Sc}=$ striatum ipsi-, contralateral). Values are given as $\mathrm{nmol} \mathrm{GSH} / \mathrm{mg}$ prot.

Mean \pm S.D. * Significance of corresponding values of Kss control group.

\# Significance of corresponding values of QA-treated group. (Student's t-test, $p<0.05$ ).

sults show a general reduction in glutathione production in ipsi- and contralateral striatum compared to the Kss animals (ipsilateral striatum $=175.819 \pm 29.181$; contralateral striatum $=139.272 \pm 25.169)$. There was no statistically significant difference in content of total glutathione obtained from each hemisphere, although injection site was in ipsilateral striatum. 7-NI treatment followed by QA clearly revealed the higher levels of glutathione in ipsi- and contralateral brain structures compared to Kss group (ipsilateral striatum $=175.819 \pm 29.181$; contralateral striatum $=$ $139.272 \pm 25.169)$. L-NAME+QA, L-NAME + ss and $7-\mathrm{NI}+$ ss treatment showed a significant increase in glutathione levels in contralateral striatum compared to Kss group (contralateral striatum $=139.272 \pm$ 25.169). Content of total glutathione was significantly increased in ipsi- and contralateral striatum of NOS inhibitors-treated animals as well as in Kss group compared to QA-treated animals (ipsilateral striatum = $101.025 \pm 23.352$; contralateral striatum $=106.127 \pm$ 19.346). Glutathione levels evidently decreased in ipsiand contralateral striatum of Koo animals compared to Kss group (ipsilateral striatum $=175.819 \pm 29.181$; contralateral striatum $=139.272 \pm 25.169$ ). Finally, content of total glutathione was increased in ipsilateral striatum of Koo group compared to QA-treated animals (ipsilateral striatum $=101.025 \pm 23.352$ ).

\section{Content of total glutathione}

in the rat forebrain cortex

The effect of different intrastriatal drug injections on the content of total glutathione in forebrain cortex is shown in Figure 2. The effect of 7-NI+QA, 7-NI+ ss and L-NAME+QA on glutathione levels in ipsi- and contralateral forebrain cortex was in a significant increase compared to Kss animals (ipsilateral forebrain cortex $=146.083 \pm 26.56$; contralateral forebrain cortex $=126.415 \pm 21.132$ ). The content of total glutathione was decreased in ipsi- and contralateral forebrain cortex in Koo animals compared with Kss group (ipsilateral forebrain cortex $=146.083 \pm 26.56$; contralateral forebrain cortex $=126.415 \pm 21.132$ ). LNAME+QA, 7-NI+QA and 7-NI+ ss treatment in ipsiand contralateral forebrain cortex showed a significant increase in glutathione levels compared to QA-treated animals (ipsilateral forebrain cortex $=116.916 \pm$ 21.639; contralateral forebrain cortex $=129.767 \pm$ 20.594). There was not statistically significant difference in content of total glutathione obtained from each hemisphere.

\section{Content of total glutathione in the rat basal forebrain}

Results obtained from this brain structure (Figure 3) were similar to the previous related to striatum. Content of total glutathione was mutually depleted in ipsi- and contralateral basal forebrain of QA-treated 


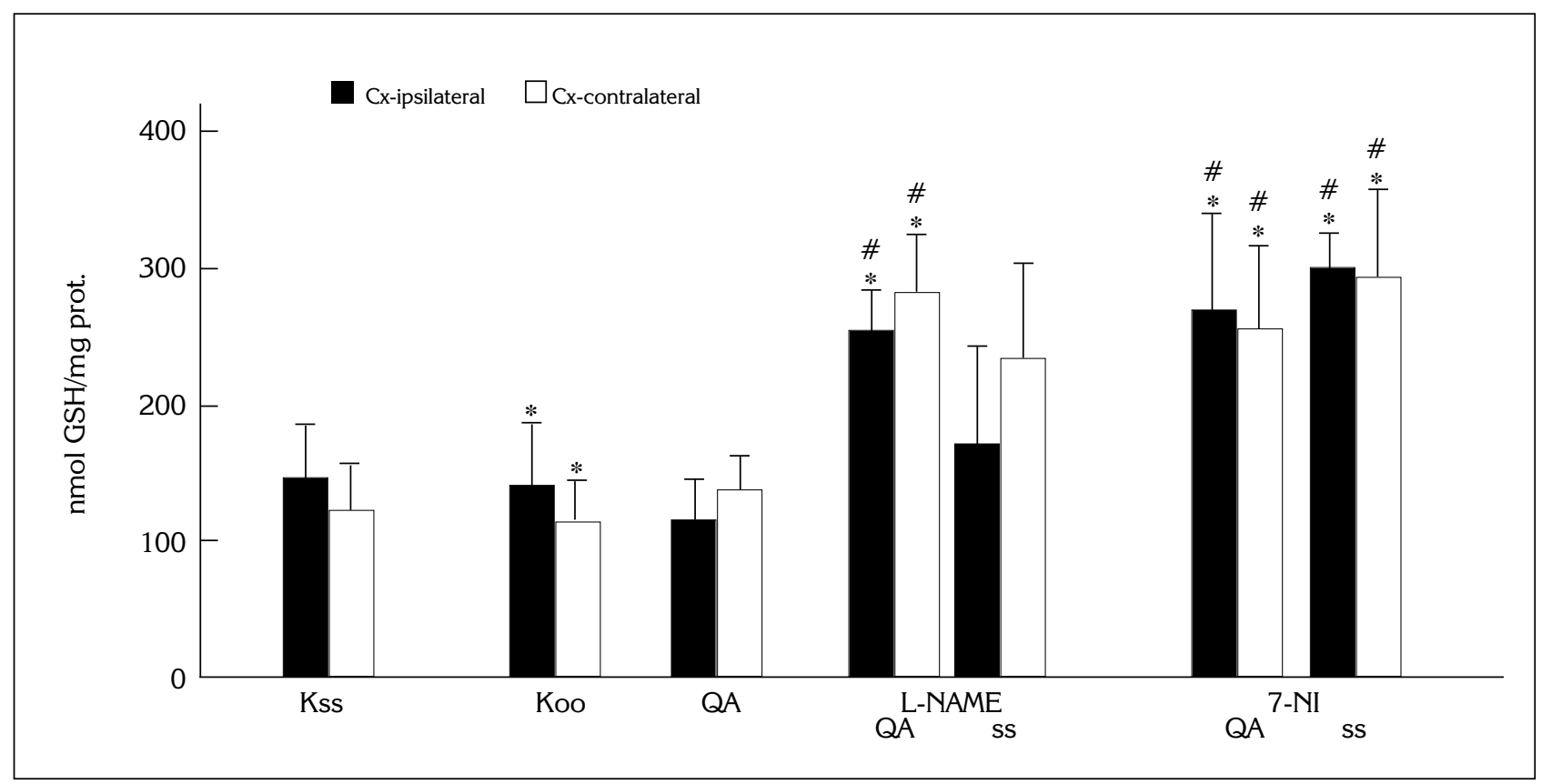

Figure 2. Content of total glutathione in the ipsi- and contralateral forebrain cortex of QA- and NOS inhibitors-treated Wistar rats. (Cxi, $\mathrm{Cxc}=$ forebrain cortex ipsi-, contralateral). Values are given as nmol GSH/mg prot.

Mean \pm S.D. * Significance of corresponding values of Kss control group.

\# Significance of corresponding values of QA-treated group. (Student's t-test, $\mathrm{p}<0.05$ ).

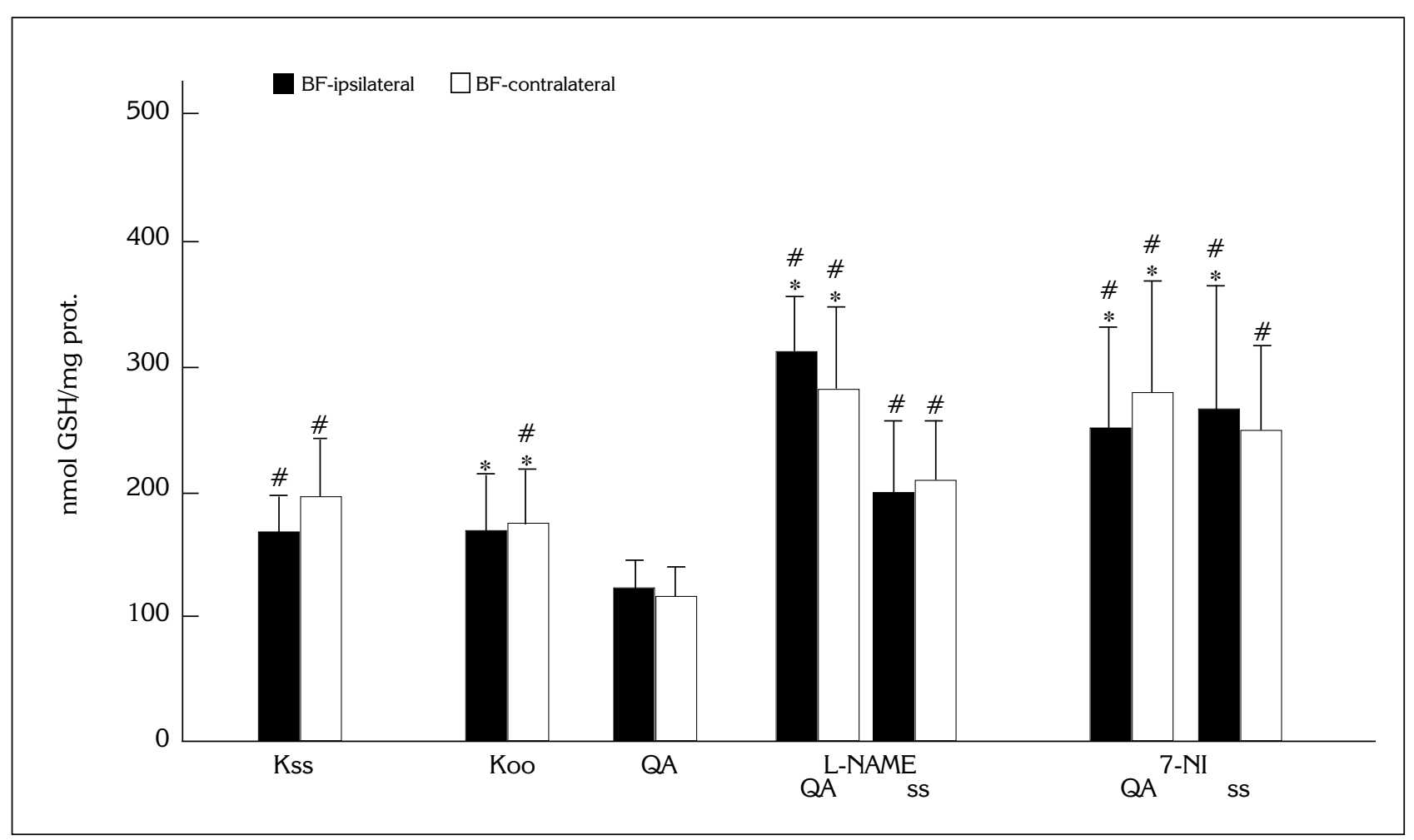

Figure 3. Content of total glutathione in the ipsi- and contralateral basal forebrain of QA- and NOS inhibitors-treated Wistar rats. (BFi, BFc = basal forebrain ipsi-, contralateral). Values are given as $\mathrm{nmol} \mathrm{GSH} / \mathrm{mg}$ prot.

Mean \pm S.D. * Significance of corresponding values of Kss control group.

\# Significance of corresponding values of QA-treated group. (Student's t-test, $\mathrm{p}<0.05$ ). 
animals compared to Kss group (ipsilateral basal forebrain $=177.048 \pm 21.712$; contralateral basal forebrain $=193.665 \pm 42.253)$. The effect of L-NAME+QA, 7$\mathrm{NI}+\mathrm{QA}$ and Koo control group in ipsi- and contralateral basal forebrain and 7-NI+ ss in ipsilateral basal forebrain on glutathione levels showed a significant increase compared to Kss group (ipsilateral basal forebrain $=177.048 \pm 21.712$; contralateral basal forebrain $=193.665 \pm 42.253$ ). There was a significant increase in glutathione levels after NOS inhibitorstreated animals and Kss animals in ipsi- and contralateral basal forebrain, as well as in contralateral basal forebrain of Koo animals compared to QA-treated group (ipsilateral basal forebrain $=134.755 \pm$ 27.829; contralateral basal forebrain $=124.592 \pm$ 29.944). There was no statistically significant difference in content of total glutathione obtained from each hemisphere.

\section{Content of total glutathione in the rat hippocampus}

The effect of different intrastriatal drug injections on glutathione levels in hippocampus is shown in Figure 4. The effect of QA-treated group and Koo group on content of total glutathione showed a significant reduction compared to Kss animals (ipsilateral hippocampus $=188.155 \pm 20.358$; contralateral hippocampus $=177.581 \pm 20.681)$. L-NAME+QA showed a significant increase in glutathione levels both in ipsi- and contralateral side compared to Kss animals (ipsilateral hippocampus $=188.155 \pm 20.358$; contralateral hippocampus $=177.581 \pm 20.681$ ). Content of total glutathione was significantly increased in the ipsi- and contralateral hippocampus of NOS inhibitors-treated animals, as well as in Kss group compared to QA-tre-ated animals (ipsilateral hippocampus $=122.555 \pm 20.733$; contralateral hippocampus $=122.31 \pm 25.855)$.

\section{Discussion}

Bioenergetic defects and oxidative stress could be critical links in excitotoxic mechanisms of neuronal death. Imbalance between production and removal of free radicals would be abrasive for a neuron (15). Increase in intracellular levels of reactive oxygen species (ROS), frequently referred to as oxidative stress, is a potentially toxic insult which, if not counteracted, will lead to membrane dysfunction, DNA damage and inactivation of proteins. Glutathione-associated metabolism is a major mechanism of cellular protection against agents generated in oxidative stress. Glutathione tripeptide is central in a complex multifaced detoxification system, where there is a substantial inter-dependence among separate component members. Glutathione provides a cell with multiple defences not only against ROS but also against their toxic products (16). A reduced form of this nonprotein thiol is the main endogenous antioxidative compound responsible for control of redox state in the cell as well as in the extracellular space (17).

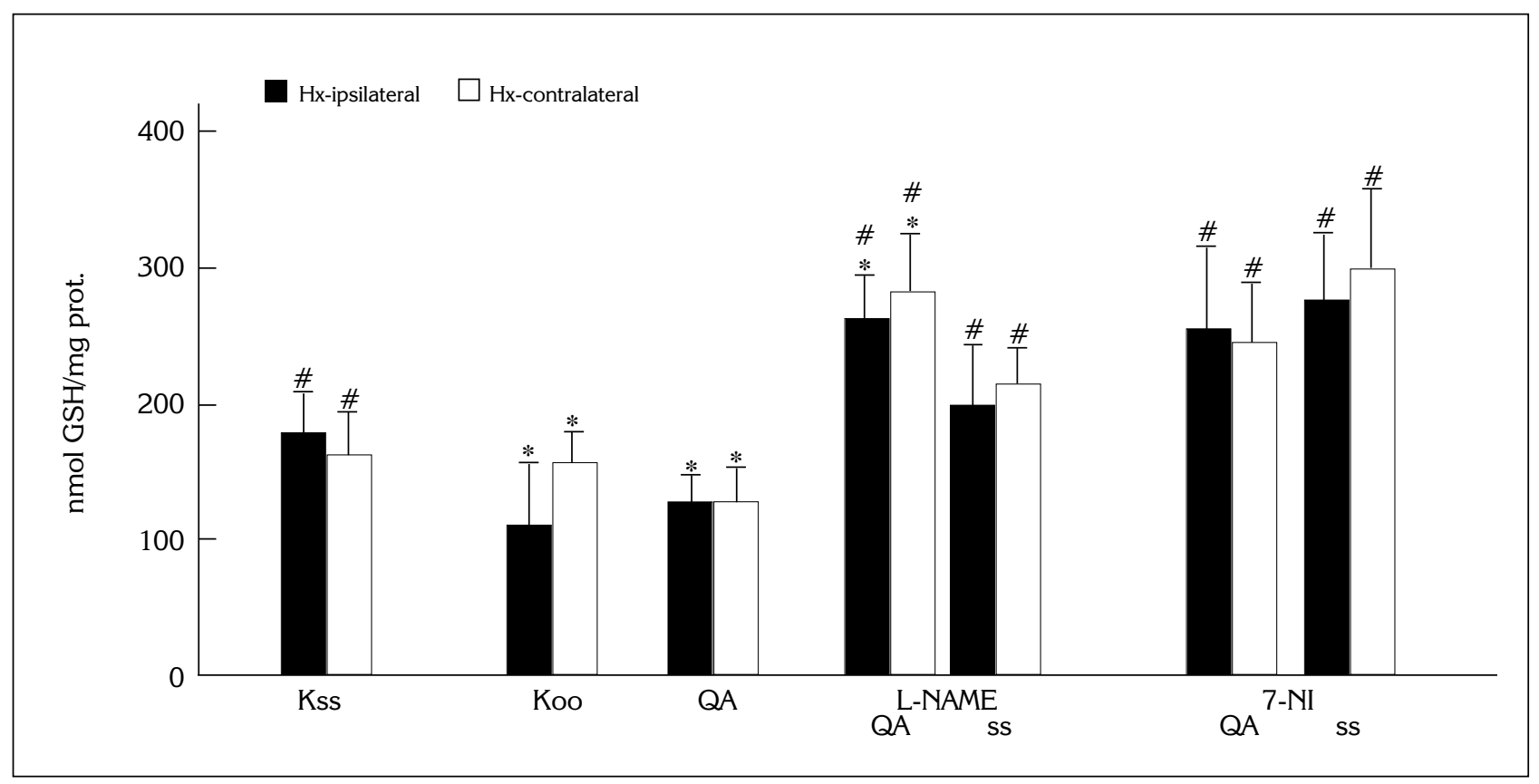

Figure 4. Content of total glutathione in the ipsi- and contralateral hippocampus of QA- and NOS inhibitors-treated Wistar rats. (Hi, Hc = hippocampus ipsi-, contralateral). Values are given as nmol GSH/mg prot. Mean \pm S.D. * Significance of corresponding values of Kss control group.

\# Significance of corresponding values of QA-treated group. (Student's t-test, p < 0.05). 
QA may lead to the generation of free radicals since it can induce lipid peroxidation in the brain. There could be a connection between the found decrease in GSH level in ipsi- and contralateral striatum of QAtreated animals and this secondary oxidative stress (Figure 1). Hydrogen peroxide, formed in the respiratory chain among the other toxic oxygen forms, if not reduced (process dependent on GSH-redox cycle) can induce a generation of aggressive hydroxyl radicals and consequent membrane lipid peroxidation. Oxidation of glutathione could disrupt $\mathrm{Ca}^{2+}$ homeostasis through the oxidation of protein thiol groups of the inner mitochondrial membrane leading to increase of free cytosolic $\mathrm{Ca}^{2+}$ which initiates many potentially toxic reactions dangerous for cell integrity (18). Once activated the chain of free radical reactions has a characteristic spread and propagation of cascade reactions, respectively, with amplifying the initial effects. It means that chain reactions, spread in space and time, lead to the neuronal cell death. These observations are supported by the observed involvement of contralateral striatum, basal forebrain and hippocampus, which are spaciously relatively distinct from ipsilateral striatum, the place of direct neurotoxine use (Figures 1, 3, 4).

QA kills hippocampal neurons via an oxidative pathway associated with total glutathione depletion. NMDA receptor activation increases NO synthesis probably by increasing intracellular calcium which binds to calmodulin, allowing it to activate NOS (19). Striatal use of QA is associated with neuronal damage through NMDA receptor activation, increased NOS activity and decrease in the total glutathione content. Decreased total glutathione content in the basal forebrain and hippocampus, the structures distant from ipsilateral treated striatum, could indicate a spatial propagation of oxidative stress, not only in the selectively vulnerable striatal GABA-ergic neurons but in the structures included in the motor and cognitive loops of basal ganglia (Figures 3, 4).

NOS inhibitors were proposed as the candidates for the treatment of neurodegenerative disease (20). 7NI and l-NAME differentially protect striatal and cortical projection neurons and interneurons against the injection of NMDA receptor agonist, QA.

Selective inhibition of nNOS by pharmacological agents such as 7-NI reduces lesion, reinforcing the idea that nNOS contributes to excitotoxic neuronal damage (21). In the present study we report on that 7$\mathrm{NI}$ increased the content of total glutathione in ipsiand contralateral striatum, forebrain cortex, basal forebrain and hippocampus compared to QA-treated animals. Moreover, the less selective nNOS inhibitor LNAME altered not the content of total glutathione in ipsi- and contralateral forebrain cortex when the LNAME + saline solution were acutely used to the rat striatum (Figure 2). Excessive NOS dependent on NO release during high levels of NMDA receptor stimulation results in production of toxic hydroxyl radicals and nitrogen dioxide. In the present report 7-NI was effective in elevation of total glutathione content in the forebrain cortex, while L-NAME was ineffective. One possible explanation of these results is the relative specificity of the two compounds in nNOS. While the neuroprotective properties of 7-NI are likely an antagonism of nNOS, the trend toward increased lesion with LNAME may have resulted from nonspecific antagonism of eNOS. The relative effectiveness of NOS antagonists as neuroprotectants may in part depend on their relative specificity of the neuronal form of NOS.

According to the assumption that L-NAME, a non-specific potent NOS inhibitor, protects neurons from reactive oxigen species, we found increased total glutathione content in ipsi- and contralateral striatum, basal forebrain and hippocampus. These effects of LNAME could be due to the influence on the cellular antioxidant defence system, stimulated cellular repair system or decreased slow excitotoxicity effects and their spatial and temporal propagation (22). L-NAME indirectly regulates the metabolism of glutathione, a small reduced peptide, involved in the detoxification of free radicals (23). Content of total glutathione was increased in ipsi- and contralateral striatum, basal forebrain and hippocampus of L-NAME+QA and LNAME + saline solution treated animals, as well as in ipsi- and contralateral forebrain cortex of L-NAME+ QA treated animals compared to QA-treated group. This indicates that the main protective influence of L-NAME includes its direct and indirect participation in glutathione metabolism and its effects on cellular homeostasis.

The content of total glutathione, as a indicator of reduced cell atmosphere, was mutually depleted in ipsilateral striatum and contralateral basal forebrain of olive oil-control group (Koo) compared to QA-treated animals (Figures 1,3). Synthesis of GSH is closely related to the cell redox state represented by $\mathrm{NAD}(\mathrm{P}) \mathrm{H} / \mathrm{NAD}(\mathrm{P})$ ratio that is dependent on glucose6-phosphate dehydrogenase activity. GSH depletion could contribute to neuronal apoptosis in HD through oxidative stress and mitochondrial dysfunction (24).

The age-related onset and progressive course of HD may be due to a cycling process between impaired energy metabolism and oxidative stress. The deleterious networks in the brain of HD are formed on the basis of the intimate interactions among the key pathogenic factors, including oxidative damage, aberrant calcium homeostasis and metabolic compromise. The present results indicate that striatal lesions induced changes in the functional activity of basal ganglionic nuclei and NOS inhibitors partly reversed the alterations in the functional state of the basal ganglia circuitry. In our study the in vivo cytoprotective effects of NOS inhibitors against striatal excitotoxic lesions suggest that both 7-NI and l-NAME could be used as potential neuroprotective agents in HD, which has been suggested to involve excitotoxicity. 


\title{
EFEKTI RAZLIČITIH INHIBITORA AZOT OKSID SINTAZE NA OŠTEĆENJE NEURONA INDUKOVANO HINOLINSKOM KISELINOM KOD PACOVA
}

\author{
Ivana D. Vasiljević1, Marina D. Jovanović1 ${ }^{1}$ Miodrag Čolić1, Rosa Mihajlović2, \\ Mirjana Đukić3 ${ }^{3}$, Milica Ninković1, Živorad Maličević ${ }^{1}$ \\ IInstitut za medicinska istraživanja, Vojnomedicinska akademija \\ Institut za rehabilitaciju \\ 3Farmaceutski fakultet, Beograd
}

\begin{abstract}
Kratak sadržaj: Etiologija selektivnog umiranja neurona u neurodegenerativnim bolestima je nepoznata, iako postoje dokazi o defektu energetskog metabolizma, ekscitotoksičnosti i oksidativnom oštećenju. Verovatno je da ključnu ulogu ima kompleksna interakcija između ovih mehanizama. Cilj ovog rada bio je da se ispitaju efekti intrastrijatne primene selektivnog inhibitora neuronske azot oksid sintaze, 7-nitroindazola, kao i nespecifičnog inhibitora azot oksid sintaze, N $\omega$-nitro-l-arginin metil estra, zbog moguće uključenosti glutationa, ključnog antioksidansa, u toksičnost strijatuma izazvanu hinolinskom kiselinom, kod pacova. Unilateralna aplikacija hinolinske kiseline, u strijatum pacova u pojedinačnoj dozi od $150 \mathrm{nmol} / \mathrm{L}$ korišćena je kao model Hantingtonove bolesti. Druge grupe životinja tretirane su 7-nitroindazolom, odnosno N $\omega$-nitro-l-arginin metil estrom. Kontrolne grupe dobijale su fiziološki rastvor, odnosno maslinovo ulje. Sadržaj ukupnog glutationa je povećan u ipsi- i kontralateralnom strijatumu, kori prednjeg mozga, bazalnom prednjem mozgu i hipokampusu grupa životinja koje su pored hinolinske kiseline primile i odgovarajući inhibitor neuronske azot oksid sintaze, u poređenju sa grupom tretiranom samo neurotoksinom. Ovi podaci pokazuju da kiseonični slobodni radikali učestvuju u ekscitotoksičnom oštećenju neurona, kao i da inhibitori azot oksid sintaze mogu biti potencijalni neuroprotektivni agensi u Hantingtonovoj bolesti.
\end{abstract} tion

Ključne reči: Hantingtonova bolest; hinolinska kiselina; N $\omega$-nitro-l-arginin metil estar; 7-nitroindazol; gluta-

\section{References}

1. Hansson O, Guatteo E, Mercuri NB, Bernardi G, Li XJ, Castilho RF, Brundin P. Resistance to NMDA toxicity correlates with appearance of nuclear inclusions, behavioural deficits and changes in calcium homeostasis in mice transgenic for exon 1 of the huntington gene. Eur J Neurosci 2001; 14 (9): 1492504.

2. Tkac I, Keene CD, Pfeuffer J, Low WC, Gruetter R. Metabolic changes in quinolinic acid-lesioned rat striatum detected non-invasively by in vivo (1)H NMR spectroscopy. J Neurosci Res 2001; 66 (5): 8918.

3. Popoli P, Pintor A, Domenici MR, Frank C, Tebano MT, Pezzola A, Scarchilli L, Quarta D, Reggio R, MalchiodiAlbedi F, Falchi M, Massotti M. Blockade of striatal adenosine $\mathrm{A} 2 \mathrm{~A}$ receptor reduces, through a presynaptic mechanism, quinolinic acid-induced excitotoxicity: possible relevance to neuroprotective interventions in neurodegene-rative diseases of the striatum. J Neurosci 2002; 22 (5): 196775.

4. Harris CA, Miranda AF, Tanguay JJ, Boegman RJ, Beninger RJ, Jhamandas K. Modulation of striatal quinolinate neurotoxicity by elevation of endogenous brain kynurenic acid. Brit J Pharmacol 1998; 124: 3919.

5. Moroni F. Trytophan metabolism and brain function: focus on kynurenine and other indole metabolites. Europ J Pharmacol. 1999; 375: 87100.
6. Chabrier PE, Demerle-Pallardy C, Auguet M. Nitric oxide synthases: targets for therapeutic strategies in neurological diseases. Cell Mol Life Sci 1999; 55 (8 9): 102935.

7. Deckel AW, Gordinier A, Nuttal D, Tang V, Kuwada C, Freitas R, Gary KA. Reduced activity and protein expression of NOS in R6/2 HD transgenic mice: effects of LNAME on symptom progression. Brain Res 2001; 919 (1): 7081.

8. Deckel AW. Nitric oxide and nitric oxide synthase in Huntington's disease. J Neurosci Res 2001; 64 (2): 99 107.

9. Blundell TL, Burke DF, Chirgadze D, Dhanaraj V, Hyvonen M, Innis CA, Parisini E, Pellegrini L, Sayed M, Sibanda BL. Protein-protein interactions in receptor activation and intracellular signalling. Biol Chem 2000; 381 (9 10): 9559.

10. Žekić RV, Štajn AŠ, Saičić YS, Spasić MB, Milovanović SR. Antioksidacioni zaštitni sistem. In: Žekić RV, Štajn Aš, Saičić YS, Spasić MB, Milovanović SR. Toksikološki značaj zaštite od oksidacionih oštećenja. Kragujevac: prirodno matematički fakultet; 2000. p.18 35.

11. Overbokk KK, Svardal A. The effect of glutathione modulation on the concentration of homocysteine in plasma of rats. Pharmacol Toxicol 2000; 87 (3): 1037. 
12. Gurd JW, Jones LR, Mahler HR, Moore WJ. Isolation and partial characterization of rat brain synaptic membrane. J Neurochem 1974; 22: 28190.

13. Anderson ME. Tissue glutathione. The DTNB-GSSG reductase recycling assay for total glutathione (GSH+ 1/2GSSG). In: Greenwald RA. CRC Press, Inc; 1986. p. 31723.

14. Lowry OH, Passonneau JV. In: A flexible system of enzymatic analysis. Academic Press, New York 1974.

15. Haik KL, Shear DA, Schroeder U, Sabel BA, Dunbar GL. Quinolinic acid released from polymeric brain implants causes behavioral and neuroanatomical alterations in a rodent model of Huntington's disease. Exp Neurol 2000; 163 (2): 4309.

16. Chatterjee S, Noack H, Possel H, Keilhoff G, Wolf G. Glutathione levels in primary glial cultures: monochlorobimane provides evidence of cell type-specific distribution. Glia 1999; 27: 15261.

17. Maksimović I, Jovanović M, Čolić M, Mihajlović R, Mićić $D$, Selaković V, Ninković M, Maličević Ž, Rusić-Stojiljković $M$, Jovičić A. Oxidative damage and metabolic dysfunction in experimental Huntington's disease: selective vulnerability of the striatum and hippocampus. Vojnosanitet Pregl 2001; 58 (3): 23742.

18. Westphal RS, Anderson KA, Means AR, Wadzinski BE. A signaling complex of $\mathrm{Ca}^{2+}$-calmodulin-dependent pro- tein kinase IV and protein phosphatase 2A. Science 1998; 280: 12589.

19. Deckel AW. Nitric oxide and nitric oxide synthase in Huntington's disease. J Neurosci Res 2001; 64 (2): 99107.

20. Perez-Severiano F, Escalante B, Rios C. Nitric oxide synthase inhibition prevents acute quinolinate-induced striatal neurotoxicity. Neurochem Res 1998; 23 (10): 1297302.

21. MacKenzie GM, Jenner P, Marsden CD. Effect of 7-nitro indazole on quinolinic acid-induced striatal toxicity in the rat. Neuroreport 1995; 6 (13): 178994.

22. Santamaria A, Santamaria D, Diaz-Munoz M, EspinozaGonzalez V, Rios C. Effects of N omega-nitro-L-arginine and L-arginine on quinolinic acid-induced lipid peroxidation. Toxicol Lett 1997; 93 (2 3): 11724.

23. Shan X, Aw TY, Jones DP. Glutathione-dependent protection against oxidative injury. Pharmac Ther 1990; 47: 6171.

24. Yuceer N, Attar A, Sargon MF, Egemen N, Turker RK, Demirel $\mathrm{E}$. The early protective effects of $\mathrm{L}$-arginine and Ng-nitro-L-arginine methyl ester after experimental acute spinal cord injury. A light and electron microscopic study. J Clin Neurosci 2000; 7 (3): 23843.

Received: March 5, 2003

Accepted: August 18, 2003 